\title{
Ecological, Legal, and Methodological Principles for Planning Buffer Zones
}

\author{
Luís Fernando Carvalho Perelló1*, Demétrio Luis Guadagnin², \\ Leonardo Maltchik ${ }^{3} \&$ José Eduardo dos Santos ${ }^{4}$
}

\author{
${ }^{1}$ Institute of the Environment, Pontificia Universidade Católica do Rio Grande do Sul - PUCRS, Porto Alegre, RS, Brasil \\ ${ }^{2}$ Post-graduation Program in Animal Biodiversity, Universidade Federal de Santa Maria - UFSM, \\ Santa Maria, RS, Brasil \\ ${ }^{3}$ Post-Graduation Program in Biology, Ecology and Aquatic Ecosystem Conservation Laboratory, UNISINOS, \\ São Leopoldo, RS, Brasil \\ ${ }^{4}$ Program in Ecology and Natural Resources, Environmental Analysis and Planning Laboratory, \\ Universidade Federal de São Carlos - UFSCar, São Carlos, SP, Brasil
}

\begin{abstract}
The use of the land around protected areas may pose risks as well as benefit the conservation of biodiversity. Nevertheless, little attention has been given to their management, in the form of clearly established buffer zones (BZ). Moreover, a great deal of confusion exists around their objectives, dimension and location. In this study we review the scientific and technical literature on BZ planning and the related legislation of Argentina, Brazil, Paraguay and Uruguay. Current literature emphasizes the threats to biodiversity from the lands around protected areas, and their role to promote life quality of neighboring communities. On the other hand, neglect the negative impacts of protected areas on the use of land around them, and the potential role of these lands in supplementing or complementing the protection of species and habitats. In the countries which legislation we surveyed, the BZ guidelines are superficial and confusing. The reviewed literature does not present an applied guide for the implementation of BZ. The lack of a comprehensive perception of the relationship between protected areas and their surroundings, clear objectives for buffer zones, and scientific rules for delimitation precludes the integration of these key areas in the effort to conserve biodiversity.
\end{abstract}

Key words: Protected Areas, Zoning, Planning, Surrounding Areas, Landscape Ecology.

\section{Introduction}

The establishment of protected areas is one of the main strategies for the biodiversity conservation. However, their implementation has many challenges, once they depend on political decision processes. Most of the protected areas are restricted to fragments of ecosystems and their functioning is dependent of interactions with their surrounding areas (Machlis \& Tichnell 1985). In most tropical parks, illegal activities, such as smuggling, lumbering, farming, animal grazing, and mining, continue to exist (Terborgh \& Schaik 2002). In addition to that reduced size and lack of connectivity of these protected areas limit their capacity to fulfill the goals and objectives of their implementation, which is the conservation of the biodiversity. The international

*Send correspondence to: Luís Fernando Carvalho Perelló Institute of the Environment,

Pontificia Universidade Católica do Rio Grande do Sul - PUCRS, Av. Ipiranga, 6681, Partenon, CEP 90619-900, Porto Alegre,

RS, Brasil

E-mail: lfperello@yahoo.com.br goal of preserving $10 \%$ of each biome worldwide probably will not be achieved in regions that were intensely modified. In Brazil, federal protected areas of full protections (IUCN categories I to III) represent $4.22 \%$ of the national territory (personal communication, August 2011 by Carlos Henrique Velázquez Fernandes, ICMBio/MMA), reaching 6.15\% when the state areas are also considered (Brasil 2009), however most of these areas are small - 46\% have up to 30,000 ha (Santos-Filho 1995; personal communication, August 2011 by Carlos Henrique Velásquez Fernandes, ICMBio/MMA ).

The management of the territory around protected areas provides a unique opportunity to guarantee the main objectives of biodiversity conservation. In situ conservation outside the protected areas is a strategy to overcome the limitations of the system (Brandon et al. 1998; Glowka et al. 1994; Soares et al. 2004). Problems in management of the protected areas frequently derive from the lack or inefficiency management proposals for their surroundings (Li et al. 2009). These peripheral areas are denoted as Buffer 
zones (BZ) and they are settled to take in consideration the objectives of protected areas (Oldfield 1988; Milano 1991).

Despite that the use of the land around protected areas put in risks the conservation, it may also to benefit the conservation. However, little attention has been given in this subject to the planning of BZ. Few studies addressed their role in the conservation of biodiversity (Gotmark et al. 2000), and most of them considers only the social-economic benefits, and not its ecological functions (Heinen \& Metha 2000; Martino 2001). The Convention for Biological Diversity (CBD) does not specifically mention "buffer zones". They are seldom addressed on international and national conservation policies (Ebregt \& Greve 2000). Buffer zone was specifically discussed in only one meeting in Davos in 2008 (Unesco 2009). In Brazil, BZ have been or are being implemented in only $31 \%$ of the 137 federal protected areas (personal communication, August, 2011 by Carlos Henrique Velázquez Fernandes, ICMBio/MMA), and they were rarely mentioned in technical discussions, and usually considered as minor issue (Kinouchi 2009). The lack of specific guidelines and regulations for BZ planning limits the possibility of including such territory in the process of organizing biodiversity conservation (Wallace et al. 2005). In general, the delimitation of these areas is based on weak, arbitrary criteria, and not related to peculiarities of each protected area (Kelly \& Rotenberry 1993).

In the present study, we reviewed the ecological, legal and methodological principles that have supported the establishment of BZ. We discussed the legislation around BZ in selected South-American countries (Argentina, Paraguay and Uruguay), with a major focus on Brazilian case, in which we make some improvements recommendations. Despite of the focus on Brazil, we hope that our approach be used to support discussions on the legislation in other countries. The establishment of a BZ implies proposing management and control actions on private lands, but such initiative is strongly opposed by the owners (Hough 1988). The main issues around the establishment of buffer zones is the antagonist positions about their role (Martino 2001), the conflict between expansion of the protected area and private lands and the promotion of benefits to local people. In some countries schemes are being proposed to compensate economical losses or to provide benefits, as a payment for ecosystem services (Wallace et al. 2005; Lacher Junior et al. 1995). We believe in the principle that buffer zones should help achieve the conservation objectives of protected area. The literature focusing BZ in marine protected areas is particularly scarce and we acknowledge a bias to terrestrial ecosystems.

\section{Methods}

We reviewed articles published in scientific journals available at Web of Science, Bireme, and Scielo (www.scielo.br); publications of environmental protection agencies of Brazil and selected South-American countries; and digital libraries cipedia (www.cipedya.com), Plos (www.plos.org), CAPES homepage (http://livre.capes.gov.br), and Google Scholar (http://scholar.google.com.br). The survey was not limited to a determined period in time. We used the term "buffer zones" in English, the terms "zona de amortiguamiento" and "zona de amortiguación" in Spanish, and "zona de amortecimento", "zona tampão" and "entorno" in Portuguese, in association with the expressions "protected area" and "reserve", in the respective languages. We included only studies related to buffer zones of protected areas of full protection (IUCN I to III) and excluded other approaches, such as the buffer zones of water bodies.

In relation to the legal aspects, we reviewed and compared the analyses given to BZ in the legislation of Brazil, Argentina, Paraguay and Uruguay. We reviewed the legal history of Brazilian BZ in publications of governmental agencies - the House of Representatives (www.camara.gov.br) and Senate (www.senado.gov.br), Ministry for the Environment (www. mma.gov.br), National Environmental Council (www.mma. gov.br/conama), National Institute of the Environment and Renewable Natural Resources - Ibama (www.ibama. gov.br) and Institute Chico Mendes for the Conservation of Biodiversity (ICMBio) (www.icmbio.gov.br). We also consulted printed publications on Brazilian environmental legislation (Brasil 2008; Benjamim 2001; Rocco 2002) and references cited on retrieved documents.

\section{Buffer Zone Definitions and History}

The concept of buffering indicates that the interactions between protected areas and their surroundings are seen as negative, and should be avoided, i.e., "buffered". BZ was initially implemented as a means of protecting people and crops from animals that escaped the conservation areas and forests in India and Africa. From the 1980s, (Ebregt \& Greve 2000) the concept was broadened, and received the missions of 1) reducing human impacts on protected areas and 2) supplying the social-economic needs of the population living inside its boundaries and that benefited from the use of its natural resources before the establishment of the protected area (Ebregt \& Greve 2000; Spiteri \& Nepal 2008). This broader perspective seems to be a trend, particularly influenced by the rationales of Biosphere Reserves, where the expressions "cooperation, participation, sustainable management, contribution to the populations" are often observed (Ozyavuz \& Yazgan 2010; Unesco 2009; Nautiyal \& Kaechele 2009; Ma et al. 2009). The roles of the BZ in biosphere reserves are to reduce external negative effects derived from human activities that may affect the core area, and to promote the quality of life of the neighboring human communities (Unesco 2009).

An example of BZ definition with an exclusive focus on conservation was observed in Sayer (1991), who defines this zone as the peripheral territory of a protected area where restrictions are imposed to the use of resources, and special actions are adopted to increase its conservation value. Wild 
\& Mutebi (1997) sustained a broadest definition - any territory peripheral to a protected area which is managed to increase the positive aspects and to reduce the negative impacts of conservation on the neighboring communities and vice versa.

In the following sections, based on a landscape perspective, we discussed the mutual influence between the protected areas and their surroundings, and the opportunities to achieve the objectives of the protected areas.

\section{Influence of the Surroundings on Protected Areas}

What is the role of the surrounding areas in the management of the protected areas? Literature mentions that the surroundings should ensure protection against external threats and generate biological, social, and economic benefits. There are few studies (Nepal \& Weber 1994; Ebregt \& Greve 2000; Martino 2001) mentioning the expansion of total area of habitats for native species, which demonstrates that the addition of area available for conservation in the buffer zones is still rarely discussed and considered (Table 1).

The list of the main external threats on protected areas is quite consistent in literature (MacKinnon \& MacKinnon 1986; The Nature Conservancy 1999; Terborgh \& Schaik 2002; Granizo et al. 2006; Worboys et al. 2006). Most studies are carried out in terrestrial protected areas and mention fire, introduction of exotic species, pesticides, mining, hunting, fishing, and urban expansion as the main threats. These factors influence the animal and plant distribution, which may result in local extinctions (Luck 2007; Wittemyer et al. 2008). The main threats to the protected areas with surrounding areas are the direct and indirect results of the need of human populations to use natural resources such as water, food and shelter and energy. The establishment of a protected area attracts human occupation, increasing the threats against the biodiversity. The occupation of land surrounding the protected areas is increasing in all continents as compared to other rural areas (Wittemyer et al. 2008), and the main cause is agriculture expansion and intensification (Sherbinin \& Freudenberger 1998; Lacher Junior et al. 1995), followed by increasing tourism, building of holiday houses (Theobald \& Hobbs 2002), and attraction by job opportunities and available infrastructure (Wittemyer et al. 2008). In Brazil, some protected areas are specifically created to counteract this expansion of human occupation. Many studies try to determine the sources of such threats, to measure the magnitude of each impact, and to identify proper methods of mapping (Thomas \& Middleton 1999; Margoluis \& Salafsky 2001; Salafsky et al. 2003; Worboys et al. 2006).

Several studies stress the positive impacts of the surrounding areas on the protected areas, as a barrier against external threats. These include human access, undesirable use of the core land, and invasion by exotic species (Naiman et al. 1993, Schultz et al. 1997). The surrounding areas may also protect the core from storms, drought, and erosion, contributing to improve the environmental services supplied by the protected area, such as water sources quality (Radkins et al. 1998; Nordstrom \& Hotta 2004; Lee et al. 2003; Lowrance et al. 2002). The buffer zone can also limit indirect human impact by delaying the dispersion of undesirable animals, plants (Hanski 1982), diseases (Dobson \& May 1986), and fire (Baker 1992).

At the social-economic aspect, the management of the surrounding areas may offer some compensation to the neighboring communities that lost rights or privileges due to the establishment of the protected area. The surrounding areas may supply essential products (firewood, wood, food, and other resources) that would otherwise be obtained in the protected area (MacKinnon \& MacKinnon 1986). As they influence the organization of the exploitation of natural resources located around the protected areas, BZ could also contribute for the organization of economic relations (Henry et al. 1999; Schultz et al. 1997).

Buffer zones can also act as corridors - linking the protected area with other fragments - reducing the effects of isolation on populations (Henry et al. 1999; Schuller et al., 2000). Corridors may be an efficient tool in conservation strategies, but also present several aspects that should be considered by the managers of protected areas. Fire and diseases are mentioned in literature as impacts that easily disseminate through these "routes". Corridors located in BZ may benefit from the management of the entire landscape around them.

The surrounding areas may have either complementary protect areas, protecting habitats or species that are not represented in the core, or supplementary ones, offering more areas for already protected habitats and species. The proper management of the surrounding areas may represent

Table 1. Studies on buffer zones (BZ) around protected areas (PA) according the focus analyzed (updated in December, 2010).

\begin{tabular}{lccc}
\hline Type of influence (BZ $\rightarrow$ PA) & n & Studies \\
\hline Positive for biodiversity & 5 & Wikramanayake et al. (2004); Thomson et al. (2000); \\
Negative for biodiversity & 2 & Fotmark et al. (2000); Nepal \& Weber (1994); Hjortso et al. (2006). \\
$\begin{array}{l}\text { Positive for local communities } \\
\text { Fegative for local communities }\end{array}$ & 7 & Lynagh \& Urich (2002); Duffy et al. (2001); Nepal \& Weber (1994); Dinh et al. (2010); \\
Adhikari et al. (2009); Spiteri \& Nepal (2008); Baral \& Heinen (2007). \\
BZ = Buffer zone; PA = Protected area.
\end{tabular}


an effective territorial expansion for many populations (Ebregt \& Greve 2000), even if the surrounding areas are not submitted to the same level of use restriction as the core (Unesco 1974; Lovell \& Sullivan 2006). This role is one of the least mentioned in the reviewed literature.

\section{Influence of the protected area on the surrounding areas}

The impacts derived from creation of a protected area on the neighboring areas are the other least mentioned aspect. Whenever mentioned in literature, only socioeconomic impacts are recognized (Gurung et al. 2008). They can be either positive, due to improved infrastructure, scenery or job opportunities (Wittemyer et al. 2008), or negative, due to restrictions on rights relative to the use the land. Impacts on biodiversity outside protected areas are totally neglected.

\section{Methods for delimitation of buffer zones}

There are few studies on methods for the establishment of BZ boundaries (Reid \& Miller 1989). We did not find any general guideline. Li et al. (2009) employed multi-criteria analysis to plan a BZ in China. Silva \& Santos (2004) reviewed methods using Boolean algebra and multivariate analysis for zoning processes, which could be employed for the establishment of BZ. Focusing on national parks, Vilhena et al. (2004) used a method adapted from the Center for International Forestry Research (Prabhu et al. 1999). Alexandre et al. (2010) proposed to delimit buffer zones as a concentric area including all surrounding habitat patches needed to protect a minimum viable population. Hauff (2004) mentioned suggestions for the establishment of buffer zones based on the perception of rural communities. The planning method of Ibama - Brazilian Environmental Institute (Galante et al. 2002) suggests qualitative criteria for BZ inclusion or exclusion on cartography basis, but not a method to integrate themes. Marchioro et al. (2005) proposed subsidies for the demarcation of buffer zones through the assessment of potential impacts of oil spills, but aimed exclusively at the Abrolhos National Marine Park and the Corumbau Marine Extractive Reserve in Brazil. The Man and Biosphere Program (Unesco 1974), that established the concept of BZ as very general criteria, was used as reference for its discussion after the 1970s. In Brazil, for instance, the recent review of the boundaries of the Atlantic Forest Biosphere Reserve defined BZ arbitrarily as areas 2.5 to $10 \mathrm{~km}$ from the core zones (RBMA 2008).

\section{Buffer zones in the Brazilian legislation}

In the last 40 years, six different expressions have been used to refer to the areas neighboring protected areas and to establish guidelines for their management (Table 2). Some expressions were not clearly defined and most statements had no explicit criteria for the delimitation or management of BZ. All concepts consider exclusively the function of protecting the core area from the potential negative effects from outside (Brasil 2004).

The first legal guideline was issued in 1967, included in Act n. 5.197, establishing a range of five kilometers of neighboring land and public dams where the use, pursuit, destruction, hunting or poaching of wild animal species was prohibited. In 1979 federal act n. 84.017, which regulated national parks, recommended that infrastructure, maintenance, and work services were built beyond park boundaries, and called as “Special Use Zone”. In 1990, federal act n. 99.274 established that in the $10 \mathrm{~km}$ radius from a protected area, all the activities that could affect the biota would be subordinated to the National Environmental Council (Conama). In this year, the Conama issued Resolution n. 13, using the expressions "surroundings of the protected

Table 2. Timeline of how the land neighboring of protected areas is considered in the Brazilian legislation.

\begin{tabular}{|c|c|c|c|}
\hline Name & Source & Function & Limits \\
\hline Adjacent land & Act $5,197 / 1967$ & Regulates the use of the fauna & $5 \mathrm{~km}$ \\
\hline Special use zone and periphery & Act $84,017 / 1979$ & Regulates the location of park infrastructure & Not defined \\
\hline Neighboring areas & Act $6.902 / 1981$ & $\begin{array}{l}\text { Regulates the establishment of Ecological } \\
\text { Stations and Environmental Protection Areas }\end{array}$ & Not mentioned \\
\hline Surrounding areas & Act $99.274 / 1990$ & $\begin{array}{c}\text { Regulates Act } 6.902 / 1981 \text { relative to } \\
\text { environmental licenses }\end{array}$ & $10 \mathrm{~km}$ \\
\hline $\begin{array}{l}\text { Surroundings and surrounding } \\
\text { areas }\end{array}$ & $\begin{array}{c}\text { Conama Resolution } \\
13 / 1990^{*}\end{array}$ & $\begin{array}{c}\text { Regulates articles } 7 \text { and } 27 \text { of } \\
\text { Act } 99.274 / 1990\end{array}$ & $10 \mathrm{~km}$ \\
\hline Surroundings & $\begin{array}{c}\text { Conama Resolution } \\
10 / 1993\end{array}$ & Regulates environmental license & $\begin{array}{l}10 \mathrm{~km} \text { or according to } \\
\text { management plan }\end{array}$ \\
\hline Surroundings & Act $9.605 / 1998$ & Environmental crimes act & Not mentioned \\
\hline Buffer zone & Act $9.985 / 2000$ & $\begin{array}{c}\text { Established the National System of Conservation } \\
\text { Units (SNUC) }\end{array}$ & Not mentioned \\
\hline Buffer zone & $\begin{array}{c}\text { Conama Resolution } \\
428 / 2010\end{array}$ & $\begin{array}{c}\text { Regulates licensing of activities with significant } \\
\text { environmental impact }\end{array}$ & $3 \mathrm{~km}$ \\
\hline
\end{tabular}

${ }^{\star}$ Extinct legislation. 
areas" and "areas surrounding the units", established that in a radius of $10 \mathrm{~km}$ from the boundaries of the core, any activity that could affect the biota would require a license from the local environmental agency. This resolution was substituted in 2010 by Resolution n. 428, which reduced the perimeter to $3 \mathrm{~km}$. A definition for the surrounding area appeared firstly in 1993 in Conama Resolution n. 10, as "[...] the area of natural plant cover contiguous to the boundaries of the protected area [...]" (Brasil 2008). A definition for "buffer zone" appeared for the first time in Act n. 9.985 of 2000, which established the National System of Conservation Units (SNUC), as

"[...] the surroundings of a protected area, where human activities are submitted to specific norms and restrictions, aiming at minimizing the negative impacts on that unit." (Brasil 2004).

The application of the legislation on the BZ is still confusing. The surrounding area mentioned in Resolution $n .10$ of 1993 seemed to have the same function of the BZ, but they were restricted to continuous natural plant coverage areas. There are only two rules for the surrounding areas: a) any activity to be established in the area must be allowed by the manager of the protected area and b) all activities that may potentially impact the protected area must be submitted to a process of environmental licensing. In general, these rules have a weak practical effect. The doubts about the correct legal statement for the delimitation of BZ resulted in an issue in 2007 involving the Abrolhos National Park, eventually paralyzing all demarcation processes at the time (Gonçalves et al. 2009).

The idea of having two different concepts in the Brazilian legislation - surroundings and buffer zones - is sometimes argued to serve for different purposes. The first one is relative to the provision of some protection to the protected area, and the second one is clearly defined by the management plan. However, these purposes are not explicit in current legislation.

The adoption of fixed distances from the core boundaries disproportionately affects small and large protected areas. For example, the $10 \mathrm{~km}$ surrounding area (Conama Resolution n. 13 of 1990) applied to areas of 100 and 1000 ha would correspond respectively to 440 and 54 times the extension of the protected area (Kinouchi 2009). The area was expressively reduced under the new Resolution n. 428 of 2010, but kept the old rationale.

\section{Buffer zones in the Southern Cone of South America}

In the three other South-American countries surveyed, buffer zones receive less legal attention as compared to Brazil. The expected function of buffer zones in the legislation of Argentina and Uruguay is the protection from external threats. The Argentina legislation on protected areas does not mention the term zoning, determining that a single protected area may host more than one protection category.
In fact, the less restrictive categories could be interpreted as the buffer zones of the more restrictive areas located in their core. Act 22.351/80 establishes, for instance, that National Reserves are "[...] areas of interest for the conservation of ecological systems and for the maintenance of zone protecting a neighboring National Park [...]" (SADS 2011). As National Reserves are less restrictive than the National Parks, since they allow the "[...] promotion and development of human settlements." (SADS 2011), they may be considered as buffer zones of the parks. In Brazil there are similar situations, where Environmental Protection Areas (Áreas de Proteção Ambiental - APAs, IUCN cathegory IV and V) are protected areas of full protection.

Paraguayan legislation (Act 352/1994) lists ten possible management zones for their protected areas, including BZ. In Paraguay, BZ are defined as

"[...] the region adjacent to the entire perimeter of a Protected Wild Area. Its size may change, and its boundaries will be determined by the Management Plant of the respective Protected Wild Area. In this zone, solidarity, mutual benefit, and the required shared responsibility between the Administration of the Protected Wild Area and the community, individuals and private and governmental organizations will be expressed for the management and consolidation of the Protected Wild Area and sustainable social-economic development." (SEAM 2011)

In that country, agricultural and forestry activities are allowed in $\mathrm{BZ}$, to reduce the conflicts between the protected area objectives and surrounding land use. The law also determines the conversion of production activities into others that are more compatible with environmental protection. The definition of $\mathrm{BZ}$ in the Paraguayan legislation follows the conceptual line supported by Unesco's MaB Program when using the expressions "[...] solidarity, mutual benefit... and sustainable social-economical development $[\ldots]$ " (SEAM 2011).

In Uruguay, the legislation (Act 17.234/2000 and Act 52/2005) mentions "adjacent zones" and "influence zones"; the dimensions of these areas are not mentioned, but restrictions are established. Legislation treats the adjacent zones as protected areas. The legislation in Uruguay prioritizes the protection of biological diversity, ecosystems, and genetic material, but supports the articulation of this management with regional development plans. However, any national or local territorial ordainment plan involving works within the adjacent zones must be communicated to the federal government. This is similar to requirements present in the Brazilian legislation, where the agreement of unit manager must be obtained.

\section{Concluding Remarks}

There are still few studies on the ecological functions of buffer zones. Most studies focused socioeconomic benefits (Heinen \& Metha 2000). The surroundings of protected areas are privileged spaces for the biodiversity conservation as they may supplement or complement habitat protection. 
However, this function is largely ignored. We did not find any study focusing effects of protected areas on biodiversity outside them, as well as on planning or legal guidelines, or on the mutual influences between BZ and protected areas.

Literature emphasizes primarily the threats of land use on biodiversity of surrounding areas of protected areas. The threats almost were not explored in recent literature, despite being present in the origin of the conception of BZ. Current literature stresses the role of the surrounding areas as a place to promote the life quality of local communities.

In the countries in which legislation was surveyed, the BZ guidelines are very generic. Only the Paraguay established formally the BZ; however, there was no mention as to their perimeters or how should they be implemented. There are no clear rules defining the boundaries, functions or management of those places. In Brazil, there are two areas external to the protected areas that are recognized and with defined areas, which makes planning and management more difficult. Moreover, the BZ concept implied in the act of the National System of Conservation Units (SNUC) is protectionist - it considers the surroundings of the protected areas as a source of threat and does not mention any concern with human populations, sustainable use of resources or the capacity of biodiversity conservation.

The reviewed literature does not present a comprehensive guide for the implementation of BZ. There are only general guidelines on their possible functions and delimitation methods. This gap both makes it difficult to implement these areas, and supports our conclusions as to the low importance given to the management of the surroundings of protected areas.

The integration of protected areas with their surroundings or regional context can be accomplished through several approaches other than the establishment of buffer zones. Alternatives include embedding protected areas in largescale corridors, watershed management plans, biosphere reserves or protected areas of sustainable use categories. These approaches differ from buffer zones in several aspects, mainly if they intend to relate the accomplishment of a protected area to set of objectives. In particular, they tend to consider larger areas than usual buffer zones and that have their own set of objectives, management programs, zoning, administration structure, legislation, and challenges.

The effective conservation of biodiversity depends on strategies complementary to the creation of protected areas that are capable of conserving habitats and species in the regional landscape scale. The management of the areas surrounding the protected areas may fulfill this role and it is especially important in small protected areas, fragmented matrices, and regions that do not have other opportunities to expand their protected areas. However, the lack of clear definitions, weighing of all potential roles and mutual relationships between protected areas and their surrounding areas expose the proper organization of these spaces to benefit biodiversity and the neighboring.

\section{Acknowledgements}

This research was supported by funds Conselho Nacional de Desenvolvimento Científico e Tecnológico - CNPq (Process 142644/2008-0). Demétrio L. Guadagnin and Leonardo Maltchik hold a Brazilian Research Council - CNPq Research Productivity grants.

\section{References}

Adhikari KR et al., 2009. Irrigation intervention: a strategy for conserving biodiversity and improving food security in royal Chitwan National Park buffer zone, Nepal. Irrigation and Drainage, 58:522-537. http://dx.doi.org/10.1002/ird.443

Alexandre B et al., 2010. How can we estimate buffer zones of protected areas? a proposal using biological data. Natureza \& Conservação, 8(2):165-170. http://dx.doi.org/10.4322/ natcon.00802010

Baker WL, 1992. The landscape ecology of large disturbances in the design and management of nature reserves. Landscape Ecology, 3:181-194. http://dx.doi.org/10.1007/BF00133309

Baral N \& Heinen JT, 2007. Decentralization and people's participation in conservation: a comparative study from the Western Terai of Nepal. International Journal of Sustainable Development and World Ecology, 14:520-531. http://dx.doi. org/10.1080/13504500709469751

Benjamim AH (coord.), 2001. Direito ambiental das áreas protegidas: o regime jurídico das unidades de conservação. Rio de Janeiro: Forense Universitária. 547 p.

Brandon K et al., 1998. Parks in Peril: people, politics and protected areas. Washington: The Nature conservany e Island Press.

Brasil, 2004. Sistema Nacional de Unidades de Conservação - SNUC, Texto da Lei 9985 de 18 de julho de 2000 e vetos da Presidência da República ao PL aprovado pelo Congresso Nacional e Decreto $N^{\circ} 4.340$, de 22 de agosto de 200. Brasília: MMA/SBF. 56 p.

Brasil. Conselho Nacional de Meio Ambiente - Conama, 2008. Resoluções do Conama: resoluções vigentes publicadas entre julho de 1984 e novembro de 2008. Brasília: Conama, 2008. 928 p. Available from: <http://www.mma.gov.br/ port/conama/processos/61AA3835/LivroConama.pdf $>$.

Brasil. Ministério do Meio Ambiente - MMA. Secretaria de Biodiversidade e Florestas, 2009. Pilares para a Sustentabilidade Financeira do Sistema Nacional de Unidades de Conservação. Brasília: Departamento de Áreas Protegidas.

Dinh TS et al., 2010. Contribution of Forest Resources to Local People's Income: A Case Study in Cat Tien Biosphere Reserve, Vietnam. Journal of the Faculty of Agriculture Kyushu University, 55:397-402.

Dobson AP \& May RM, 1986. Disease and conservation. In: Soulé M (ed.). Conservation biology: The science of scarcity and diversity. Sunderland: Sinauer Associates. p. 345-365.

Duffy SB et al., 2001. Simulating land-use decisions in the La Amistad Biosphere Reserve buffer zone in Costa Rica and Panama. Ecological Modelling, 140:9-29. http://dx.doi. org/10.1016/S0304-3800(01)00266-6 
Ebregt A \& Greve P, 2000. Buffer zones and their management: Policy and Best Practices for Terrestrial Ecosystems in Developing Countries. Wageningen: International Agricultural Centre, National Reference Centre for Nature Management - EC-LNV, International Agricultural Centre - IAC. Theme Studies Series 5. Forests, Forestry and Biological Diversity Support Group. Available from: <http://www.minlnv.nl/cdlpub/servlet/ CDLServlet?p_file_id=13954>.

Fiorello CV et al., 2006. Demography, hunting ecology, and pathogen exposure of domestic dogs in the Isoso of Bolivia. Conservation Biology, 20:762-771. PMid:16909569. http:// dx.doi.org/10.1111/j.1523-1739.2006.00466.x

Galante MAV et al., 2002. Roteiro metodológico de planejamento - parque nacional, reserva biológica, estação ecológica. Ibama.

Glowka L et al., 1994. A Guide to the Convention on Biological Diversity. Gland and Cambridge: IUCN. $161 \mathrm{p}$.

Gonçalves CN et al., 2009. Zona de amortecimento: criação ou delimitação? Natureza \& Conservação, 7(2):38-43.

Gotmark F et al. 2000. Buffer zones for forest reserves: opinions of land owners and conservation value of their forest around nature reserves in southern Sweden. Biodiversity and Conservation, 9:1377-1390. http://dx.doi. org/10.1023/A:1008978831068

Granizo T et al., 2006. Manual de Planejamento para a Conservação de Áreas, PCA. Quito: TNC y USAID.

Gurung B et al., 2008. Factors associated with humankilling tigers in Chitwan National Park, Nepal. Biological Conservation, 141(12):3069-3078. http://dx.doi.org/10.1016/j. biocon.2008.09.013

Hanski I, 1982. Distributional ecology of anthropochorus plants in villages surrounded by forest. Annales Botanici Fennici, 19:1-15.

Hauff SN, 2004. Percepção de comunidades rurais sobre a implantação de Unidades de Conservação: subsídios para estabelecer zonas de amortecimento. Natureza \& Conservação, 2:32-47.

Heinen J \& Mehta J, 2000. Emerging issues in legal and procedural aspects of buffer zone management with case studies from Nepal. The Journal of Environment \& Development, 9(1):45-67. PMid:19552863. http://dx.doi. org/10.1177/107049650000900103

Henry AC et al., 1999. Conservation corridors in the United States: benefits and planning guidelines. Soil Water Conservation, 54(4):645-650.

Hjortso CN et al., 2006. Applying multi-criteria decision-making to protected areas and buffer zone management: A case study in the Royal Chitwan National Park, Nepal. Journal of Forest Economics, 12:91-108. http://dx.doi.org/10.1016/j. jfe.2006.03.001

Hough JL, 1988. Obstacles to effective management of conflicts between national parks \& surrounding human communities in developing countries. Environmental Conservation, 15:129-136. http://dx.doi.org/10.1017/S0376892900028939

Kelly PA \& Rotenberry JT, 1993. Buffer zones for ecological reserves in California: Replacing guesswork with science.
In: Keeley JE (ed.). Interface between ecology and land development in California. Los Angeles: Southern California Academy of Science. p. 85-91.

Kinouchi MR, 2009. Uma aproximação sobre a representatividade territorial das categorias geoespaciais "zona de amortecimento" e "entorno" nas unidades de conservação brasileiras. In: Anais 6th Congresso Brasileiro de Unidades de Conservação; 2008; Curitiba. Curitiba: Fundação o Boticário para a Proteção da Natureza.

Lacher Junior TE et al., 1995. Incentivos Economicos y de Conservación para El Manejo de las Zonas de Amortiguamiento: La Iniciativa Amisconde. In: Fonseca GAB, Schmink M, Pinto LPS \& Brito F. Abordagens Interdisciplinares para a Conservação da Biodiversidade e Dinâmica do Uso da Terra no Novo Mundo. Belo Horizonte: Conservation International do Brasil, Universidade Federal de Minas Gerais; Gainesville: University of Florida. p. 315-334.

Lee KH et al., 2003. Sediment and nutrient removal in an established multi-species riparian buffer. Journal of Soil and Water Conservation, 58(1):1-10.

Li W et al., 2009. Designing the buffer zone of a nature reserve: a case study in Yancheng Biosphere Reserve, China. Biological Conservation, 90:159-165. http://dx.doi.org/10.1016/ S0006-3207(99)00011-7

Lovell ST \& Sullivan WC, 2006. Environmental benefits of conservation buffers in the United States Evidence, promise, and open questions. Agriculture, Ecosystems and Environment, 112:249-260. http://dx.doi.org/10.1016/j.agee.2005.08.002

Lowrance R et al., 2002. Improving water and soil quality with conservation buffers. Soil Water Conservation, 57:36-43.

Luck GW, 2007. A review of the relationships between human population density and biodiversity. Biological Reviews, 82:607. PMid:17944620. http:// dx.doi.org/10.1111/j.1469-185X.2007.00028.x Lynagh FM \& Urich PB, 2002. A critical review of buffer zone theory and practice: A Philippine case study. Society \& Natural Resources, 15:129-145. http://dx.doi. org/10.1080/089419202753403319

Ma ZJ et al., 2009. Conflicts between biodiversity conservation and development in a biosphere reserve. Journal of Applied Ecology, 46:527-535. http://dx.doi. org/10.1111/j.1365-2664.2008.01528.x

Machlis GE \& Tichnell DL, 1985. The State of the World's Parks: an international assessment for resource management, policy, and research. London: Westview.

MacKinnon K \& MacKinnon J, 1986. Managing protected areas in the tropics. Gland: IUCN.

Marchioro et al., 2005. Subsídios para a delimitação das zonas de Amortecimento do Parque Nacional Marinho dos Abrolhos e Reserva Extrativista Marinha do Corumbau por meio da avaliação de impactos potenciais de derramamentos de óleo. Conservação Internacional Brasil. Relatório Final. Available from: <http://www.anp.gov.br/brnd/round9/ round9/guias_R9/perfuracao_R9/Bibliografia/Rel\%20 Za\%20Abrolhos.pdf>.

Margoluis R \& Salafski N, 2001. Is our Project succeeding? A guide to threat reduction Assessment for conservation. Available 
from: <http://www.fosonline.org/images/Documents/ tra.pdf $>$.

Martino D, 2001. Buffer zones around protected areas: a brief literature review. Electronic Green Journal, 1(15). Available from: <http://repositories.cdlib.org/uclalib/egj/ vol1/iss15/art2>.

Milano MS, 1991. Conservação "in situ" e sistemas de unidades de conservação: Estratégias de conservação da biodiversidade. Brasília.

Naiman RL et al., 1993. The role of riparian corridors in maintaining regional biodiversity. Ecological Applications, 3:209-212. http://dx.doi.org/10.2307/1941822

Nautiyal S \& Kaechele H, 2009. Natural resource management in a protected area of the Indian Himalayas: a modeling approach for anthropogenic interactions on ecosystem. Environmental Monitoring and Assessment, 153:253-271. PMid:18604590. http://dx.doi.org/10.1007/s10661-008-0353-Z

Nepal SK, \& Weber KE, 1994. A buffer zone for biodiversity conservation - viability of the concept in nepal royal chitwan-national-park. Environmental Conservation, 21:333-341. http://dx.doi.org/10.1017/S0376892900033646

Neumann RP, 1997. Primitive ideas: Protected area buffer zones and the politics of land in Africa. Development and Change, 28:559-582. http://dx.doi.org/10.1111/1467-7660.00054

Nordstrom KF \& Hotta S, 2004. Wind erosion from cropland in the USA: a review of problems, solutions and prospects. Geoderma. Available from: $<$ http://cat.inist.fr/?aModele= afficheN\&spsidt $=15924665>$.

Oldfield S, 1988. Buffer zone management in tropical moist forest: Case studies and guidelines. Gland: IUCN. The IUCN Tropical Forest Programme.

Ozyavuz M \& Yazgan ME, 2010. Planning of Igneada Longos (Flooded) Forests as a Biosphere Reserve. Journal of Coastal Research, 26:1104-1111. http://dx.doi.org/10.2112/ JCOASTRES-D-09-00065.1

Prabhu R, 1999. Guidelines for developing, testing and selecting criteria and indicators for sustainable forest management: a C \& I developer's reference. Bogor: CIFOR. Criteria and Indicators Toolbox Series, n.1.

Radkins Junior A et al., 1998. Minimizing herbicide and sediment losses in runoff with vegetative filter strip. Abstr. Weed Science Society, 38:59.

Reid WV \& Miller KR, 1989. Keeping options alive: The scientific basis for conserving biodiversity. Washington: World Resources Institute.

Reserva da Biosfera da Mata Atlântica - RBMA, 2008. Revisão da Reserva da Biosfera da Mata Atlântica - Fase VI/2008. Parte I - Dados Gerais, Formulário Unesco. Available from: $<$ http://www.rbma.org.br/rbma/rbma_fase_vi_04_form.asp $>$.

Rocco R, 2002. Legislação Brasileira do Meio Ambiente. Rio de Janeiro: DP\&A.

Salafsky N et al., 2003. Conventions for Defining, Naming, Measuring, Combining and Mapping Threats in Conservation An Initial Proposal for a Standard System. Conventions for
Threats in Conservation. Available from: $<\mathrm{http}: / /$ www.tpwd. state.tx.us/publications/pwdpubs/pwd_pl_w7000_1187a/ media/Conventions_for_Threats_in_Conservation.pdf $>$.

Santos-Filho PS, 1995. Fragmentação de Hábitats: implicações para a conservação in situ. In: Esteves FA (ed.). Oecologia Brasiliensis. Rio de Janeiro: Instituto de Biologia. p. 365-393. v. 1: Estrutura, funcionamento e manejo de ecossistemas brasileiros.

Sayer J, 1991. Rainforest Buffer Zones: Guidelines for Protected Area Managers. Gland: Forest Conservation Program, IUCN.

Schuller D et al., 2000. Sustainable land use in an agriculturally misused landscape in northwest Germany through ecotechnical restoration by a 'Patch-Network-Concept'. Ecological Engineering, 16:99-117. http://dx.doi.org/10.1016/ S0925-8574(00)00094-X

Schultz RC et al., 1997. Riparian Buffer Systems. Iowa State University Publication.

Secretaria de Ambiente y Desarrollo Sustentable de la Nación - SADS, 2011. Ley 22.351/80 de Parques y Reservas Nacionales y Monumentos Naturales. Disponível em: http://www.ambiente.gov.ar/?aplicacion=normativa\&Id Norma $=106 \&$ IdSeccion $=0$

Secretaria del Ambiente - SEAM, 2011. Ley 352/94 de Areas Silvestres Protegidas. Disponível em: http://www.seam.gov. py/images/stories/seam/legislacion/ley_352.pdf

Sherbinin AD \& Freudenberger M, 1998. Migration to protected areas and buffer zones: can we stem the tide? Parks, $8(1)$.

Silva JS \& Santos RF, 2004. Zoneamento para planejamento ambiental: vantagens e restrições de métodos e técnicas. Cadernos de Ciência \& Tecnologia, 21(2):263- 221

Soares MCC, Bensusan N \& Ferreira Neto PS (org.), 2004. Entorno de Unidades de Conservação: estudo de experiências com UCs de proteção integral. Rio de Janeiro: Funbio. 112 p.

Spiteri A \& Nepal SK, 2008. Distributing conservation incentives in the buffer zone of Chitwan National Park, Nepal. Environmental Conservation, 35:76-86. http://dx.doi. org/10.1017/S0376892908004451

Terborgh J \& Schaik C, 2002. Por que o Mundo Necessita de Parques. In: Terborgh J, Schaik CV, Davenport L \& Rao M (org.). Tornando os Parques Eficientes: estratégias para a conservação da natureza nos trópicos. Curitiba: Editora da UFPR, Fundação O Boticário.

The Nature Conservancy, 1999. Planejamento para a conservação de áreas protegidas: Um método para desenvolver e avaliar o impacto de estratégias eficazes de conservação da biodiversidade. Available from: <http://www.google. com.br/search?q=planejamento+para+a+conserva $\% \mathrm{C} 3$ $\% \mathrm{~A} 7 \% \mathrm{C} 3 \% \mathrm{~A} 3 \mathrm{o}+\mathrm{de}+\% \mathrm{C} 3 \% \mathrm{~A} 1$ reas + protegidas + The $+\mathrm{n}$ ature + conservancy $\&$ ie $=$ utf $-8 \&$ oe $=$ utf $-8 \&$ aq $=$ t $\&$ rls $=$ org . mozilla:pt-BR:official\&client=firefox-a $>$.

Theobald DM \& Hobbs NT, 2002. A Framework for evaluating land use planning alternatives: Protecting biodiversity on private land. Conservation Ecology, 6:5. Disponível em: www.ecologyandsociety.org/vol6/iss1/art5. 
Thomas L \& Middleton J, 1999. Guidelines for Management Planning of Protected Areas. Cambridge: IUCN. Practice Protected Area Guidelines (World Commission on Protected Areas - WCPA Series, n.10).

Thomson PC et al., 2000. The effectiveness of a large-scale baiting campaign and an evaluation of a buffer zone strategy for fox control. Wildlife Research, 27:465-472. http://dx.doi. org/10.1071/WR99036

Unesco, 1974. Task force on: Criteria and guidelines for the choice and establishment of biosphere reserves. Paris: Unesco. 61 p. Final report, MAB report series, n. 22.

Unesco, 2009. International Expert Meeting on World Heritage and Buffer Zones. Paris: World Heritage and Buffer Zones. Available from: <http://whc.unesco.org/documents/ publi_wh_papers_25.pdf $>$.

Vilhena $\mathrm{F}$ et al., 2004. Parámetros para la delimitación y manejo adaptativo de zonas de amortiguamiento en parques nacionales del Cerrado, Brasil. Recursos Naturales y Ambiente. Available from: <http://cmbbc.cpa.embrapa. br/Artigo\%20ZAM-Flavia.pdf>.
Wallace GN et al., 2005. Planejamento da ocupação do solo e regulamentação para o entorno de unidades de conservação: um estudo de marcos legais, melhores práticas e necessidades de capacitação no México e na América Central. Natureza \& Conservação, 3:64-42.

Wikramanayake E et al., 2004. Designing a conservation landscape for tigers in human-dominated environments. Conservation Biology, 18:839-844. http://dx.doi. org/10.1111/j.1523-1739.2004.00145.x

Wild R \& Mutebi, J, 1997. Bwindi impenetrable forest, Uganda: Conservation through collaborative management. Nature and Resources, 33:33-51.

Wittemyer G et al., 2008. Accelerated Human Population Growth at Protected Area Edges. Science, 321:123-126. PMid:18599788. http://dx.doi.org/10.1126/science.1158900

Worboys GL et al., 2006. Threats to Protected Areas. In: Lockwood M, Worboys GL \& Kothari A. (ed.). Managing Protected Areas: a global guide. London: Earthscan. 802 p.

Received: April 2011 First Decision: June 2011 Accepted: February 2012 